mentation. The discussion includes contributions from Dr. F. Steggerda, director of the Nederlandsch Instituut voor Documentatie en Registratuur, and Dr. C. Groeneveld, of the Royal Dutch Shell Laboratory, and indicates the wide variety of practice. Two points which might be noted in passing are: first, the importance of relating the filing system to the quantity of material it is called upon to handle ; and secondly, that notably in regard to correspondence, the papers and discussion collected in this report indicate a number of factors in efficient registry service which should be impressed firmly on all those using correspondence files, whether they bear any responsibility or not for the filing system itself. 51 :

\section{Delinquency among Young People in Colombia}

Is Revista de la Universidad del Cauca (No. 9, June 1946), Luis Gakes Pérez deals with factors responsiblefor cripte among young people in Colombia. The author fovides statistics based upon the results of certnn mvestigations, in particular of the cases wherp there has been death of one or both parents, an Whese present some interesting features. When the mother survives, the number of delinquents increases, but when the father survives it decreases ; the greatest number comes from cases where both parents are alive. Offences against property are by far the most numerous, and next to these, but very much less numerically, are offences against persons and cases of vagrancy. Cases of lapses after reformatory treatment are numerous; they suggest that it has no effect or that the teaching is practically the negation of correctional. Other matters are discussed, such as the larger number of male than of female criminals, the criminality of women in Colombia (in 1944, out of a total of 5,217 people condemned for offences, only a little more than 6 per cent were women), the problem of crime among the Indians, the Indian in relation to the law in Colombia, etc. In connexion with the last point, there is no general legislation; the protectors and judges of the Indians are usually the missionaries. They are authorized to exercise civil, penal and judicial jurisdiction over them, in accordance with a law passed in 1890 . Difficulties arise in those cases where it is not very easy to differentiate between Indians who are civilized and those who are not. The methods for obviating this difficulty are by no means ideal, and alterations in the system are matters of great importapce.

\section{Fruit Production and Propagation}

THe war-tinge gapofntration on food production and the turning of 10 f pany fruit-tree nurseries to shortterm crpes. has resulted in an acute shortage of rounghrees to meet the needs of the expanding injodstry and the private garden alike. In addition, mach experienced labour has been lost to the industry in general, so there is real need to make known in a practical form the most up-to-date methods of propagation and the accumulated experience of orchard management. These objects are admirably achieved by two recent pamphlets issued by the Ministry of Agriculture and Fisheries ("Apples and Pears". Bull. 133. Pp. $119+18$ plates. $2 s .6 d$. net; and "Fruit Tree Raising: Rootstocks and Propagation". Bull 135 . Pp. $46+2$ plates. 1s. $3 d$. net. London: H.M. Stationery Office). The arts of budding and grafting can only be fully acquired by observing the green-fingered dexterity of the experienced propagator, and proficiency and speed are only achieved after long practice (100 buds or 70 grafts an hour are said to be good averages); nevertheless, Bulletin No. 135 does as much as can be done by precept. It includes, inter alia, chapters on the classification and uses of rootstocks; propagation from seed, cuttings, stools and layers; tree shaping; control of pests and diseases, and a useful calendar of nursery operations.

Bulletin No. 133 is a well-illustrated text-book of commercial apple and pear production, and covers all aspects of the subject from planning and planting to storing and marketing. There is a particularly good chapter on top-working and frame-working, but that on pruning might have been improved by reference to the results of pruning and shaping trials at the research stations. In the chapter on soil management, on the other hand, the section on cover crops does not distinguish very clearly between established commercial practice and recent experimental results which have not been tested commercially. Both bulletins provide the orchardist with authoritative manuals at negligible cost.

Diseases of Cereals in Scotland

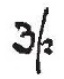

THE high atmospheric humidity in Scotland favours the rapid developmont, of eyespot (Cercosporella herpotrichoides) on whoct and barley, but the severity of the firsease is off $A$ t by the relatively long rotations

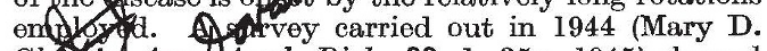

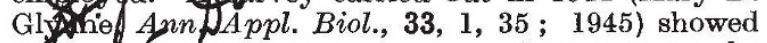
75 per clnt of the autumn-sown wheat crops to be affect de and some 9 per cent showed obvious loss. Nearly all spring-sown crops of barley were affected; but damage appeared to be less than on wheat. Sharp eyespot (Corticium Solani) was widespread and was particularly common in Aberdeenshire ; loss is apparently slight, but deep lesions may cause some straggling. Take-all disease (Ophiobolus graminis) was seen on less than half the wheat crops, and in only one case was 10 per cent of the straws affected. Except in Dumfriesshire and Aberdeenshire, it was much less common than eyespot, a conclusion similar to that reached by R. W. G. Dennis (Ann. Appl. Biol., $31,370 ; 1944)$.

\section{Coryndon Memorial Museum, Nairobi}

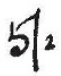

THE annuab pepoufor 1945 of the Museums Trustees of fend announces the appointment of Dr. L. S. 8. Leakey (upon his release from war duthies) to the full-time curatorship of the Coryndon Mo A rial Kuseum. Dr. Leakey, well known for his work in East African prehistory, has already carried out a great deal of work for this Museum in his capacity first as honorary curator and then as part-time curator. The Curator's report for the same year reports the holding of a Conference of Curators of East African Museums under the chairmanship of Dr. Leakey, and it is hoped that in future this will be an annual event. It was decided that a Federation of East and Central African Museums should be formed and linked with the Museums Association of England and the Empire. The same report makes reference to the possible development of the Museum as Kenya's War Memorial. During the year, the Governor called for suggestions as to what form the Kenya War Memorial should take, and a special committee was appointed to consider schemes sent in. Out of the ninety-eight 